\title{
Circulating Serum Exosomal aHIF Is A Novel Prognostic Predictor For Epithelial Ovarian Cancer [Corrigendum]
}

Tang X, Liu S, Liu Y, et al. Onco Targets Ther. 2019;12:7699-7711.

Upon reviewing the article, the authors noticed an error in Figure 1A (page 7703). The authors had mixed up and uploaded the incorrect figure panel. The authors apologize for this error. The authors confirm that the revised figure does not affect the results and conclusion of the article. The corrected version of Figure $1 \mathrm{~A}$ is as follows:
A.

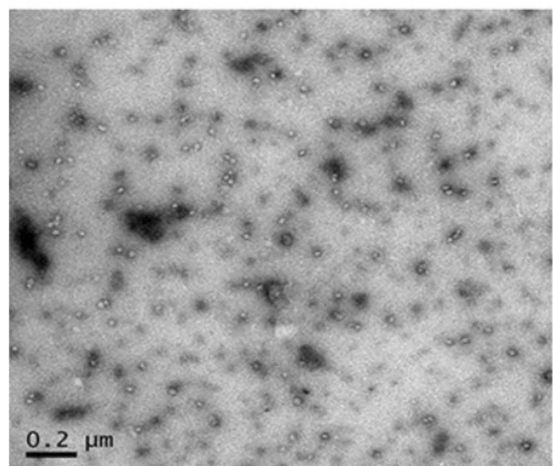

B.

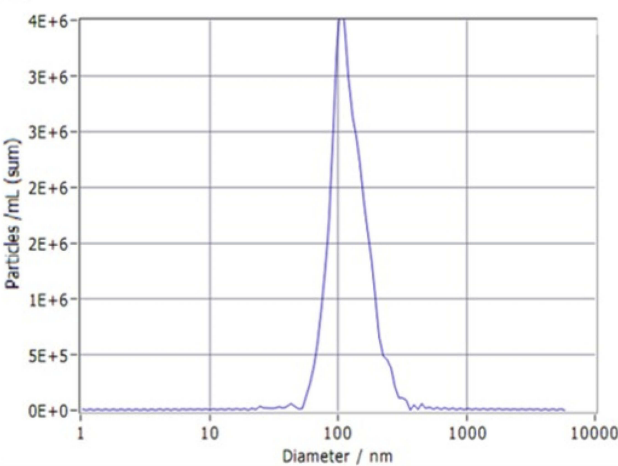

C.
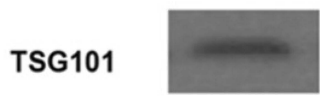

$45 \mathrm{kDa}$

CD63

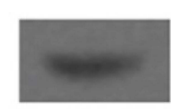

$53 \mathrm{kDa}$

HSP70

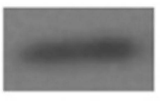

$70 \mathrm{kDa}$

HSP90

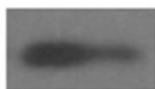

$90 \mathrm{kDa}$

Figure I Characterization of exosomes derived from serum. TEM showed exosomes derived from serum had round-shaped morphology ranged from $30 \mathrm{~nm}$ to $100 \mathrm{~nm}$ (A, scale bar $=200 \mathrm{~nm}$ ). Size distribution of exosomes through NTA revealed that average size of exosomes was I00 nm (B). Western blotting for CD63, TSGI0I, Hsp-70, Hsp-90 as exosomal markers $(\mathbf{C})$.

Abbreviations: TEM, transmission electron microscopy; NTA, nanoparticle tracking analysis.

\section{Publish your work in this journal}

OncoTargets and Therapy is an international, peer-reviewed, open access journal focusing on the pathological basis of all cancers, potential targets for therapy and treatment protocols employed to improve the management of cancer patients. The journal also focuses on the impact of management programs and new therapeutic agents and protocols on patient perspectives such as quality of life, adherence and satisfaction. The manuscript management system is completely online and includes a very quick and fair peer-review system, which is all easy to use. Visit http://www.dovepress.com/ testimonials.php to read real quotes from published authors. 